OPEN ACCESS

Edited by:

Alejandro Isabel Luna-Maldonado,

Universidad Autónoma de Nuevo

León, Mexico

Reviewed by:

Xuming Huang,

South China Agricultural University,

China

Fulai Liu,

University of Copenhagen, Denmark

*Correspondence:

Yuxin Tong

tongyuxin@caas.cn;

Qichang Yang

yangqichang@caas.cn

Specialty section:

This article was submitted to Crop Science and Horticulture,

a section of the journal

Frontiers in Plant Science

Received: 09 November 2015 Accepted: 15 February 2016

Published: 10 March 2016

Citation:

Wang J, Lu W, Tong Y and Yang Q

(2016) Leaf Morphology,

Photosynthetic Performance

Chlorophyll Fluorescence, Stomatal

Development of Lettuce (Lactuca sativa L.) Exposed to Different Ratios

of Red Light to Blue Light.

Front. Plant Sci. 7:250

doi: 10.3389/fpls.2016.00250

\section{Leaf Morphology, Photosynthetic Performance, Chlorophyll Fluorescence, Stomatal Development of Lettuce (Lactuca sativa L.) Exposed to Different Ratios of Red Light to Blue Light}

\author{
Jun Wang ${ }^{1,2}$, Wei Lu ${ }^{1,2}$, Yuxin Tong ${ }^{1,2 *}$ and Qichang Yang ${ }^{1,2 *}$
}

\begin{abstract}
1 Institute of Environment and Sustainable Development in Agriculture, Chinese Academy of Agricultural Sciences, Beijing, China, ${ }^{2}$ Key Laboratory of Energy Conservation and Waste Management of Agricultural Structures, Ministry of Agriculture, Beijing, China
\end{abstract}

Red and blue light are both vital factors for plant growth and development. We examined how different ratios of red light to blue light $(R / B)$ provided by lightemitting diodes affected photosynthetic performance by investigating parameters related to photosynthesis, including leaf morphology, photosynthetic rate, chlorophyll fluorescence, stomatal development, light response curve, and nitrogen content. In this study, lettuce plants (Lactuca sativa L.) were exposed to $200 \mu \mathrm{mol} \cdot \mathrm{m}^{-2} \cdot \mathrm{s}^{-1}$ irradiance for a $16 \mathrm{~h} \cdot \mathrm{d}^{-1}$ photoperiod under the following six treatments: monochromatic red light $(R)$, monochromatic blue light $(B)$ and the mixture of $R$ and $B$ with different $R / B$ ratios of $12,8,4$, and 1 . Leaf photosynthetic capacity $\left(A_{\max }\right)$ and photosynthetic rate $\left(P_{\mathrm{n}}\right)$ increased with decreasing R/B ratio until 1, associated with increased stomatal conductance, along with significant increase in stomatal density and slight decrease in stomatal size. $P_{\mathrm{n}}$ and $A_{\max }$ under $\mathrm{B}$ treatment had 7.6 and $11.8 \%$ reduction in comparison with those under $\mathrm{R} / \mathrm{B}=1$ treatment, respectively. The effective quantum yield of PSII and the efficiency of excitation captured by open PSIl center were also significantly lower under B treatment than those under the other treatments. However, shoot dry weight increased with increasing $R / B$ ratio with the greatest value under $R / B=12$ treatment. The increase of shoot dry weight was mainly caused by increasing leaf area and leaf number, but no significant difference was observed between $R$ and $\mathrm{R} / \mathrm{B}=12$ treatments. Based on the above results, we conclude that quantitative $\mathrm{B}$ could promote photosynthetic performance or growth by stimulating morphological and physiological responses, yet there was no positive correlation between $P_{\mathrm{n}}$ and shoot dry weight accumulation.

Keywords: R/B ratio, photosynthetic performance, chlorophyll fluorescence, stomata, dry weight, Lactuca sativa L. 


\section{INTRODUCTION}

As a signal and energy source, light is one of the most important environment factors for plant growth and development. Compared with light intensity and photoperiod, light quality shows much more complex effects on plant morphology and physiology. Specific spectrum stimulates different morphological and physiological responses. Red light (R) and blue light (B) absorbed by photosynthetic pigments are more effective than other wavelengths (Pfündel and Baake, 1990). It is well known that $\mathrm{R}$ influences stem elongation, root to shoot ratio, chlorophyll content, photosynthetic apparatus (Appelgren, 1991; Aksenova et al., 1994; Sæbø et al., 1995). B causes physiological responses via phototropins, including phototropism, hypocotyl elongation, leaf expansion, stomatal opening, leaf anatomy, enzyme synthesis, chloroplast movements, and genes expression (Christie, 2007; Inoue et al., 2008; Wang et al., 2009).

However, monochromatic $\mathrm{R}$ or $\mathrm{B}$ could not meet the requirement of plant growth. Plants under $\mathrm{R}$ alone displayed abnormal leaf morphology and reduced photosynthetic rate $\left(P_{\mathrm{n}}\right)$ compared with white light or R supplemented with B (Goins et al., 1998; Wang et al., 2009, 2015; Hogewoning et al., 2010b). Hogewoning et al. (2010b) reported that leaf photosynthetic machinery dysfunction appeared under $\mathrm{R}$ alone, only $7 \% \mathrm{~B}$ was sufficient to prevent any overt dysfunctional photosynthesis. In addition, $\mathrm{B}$ alone could also reduce $P_{\mathrm{n}}$ in many species, such as chrysanthemum plantlets (Kim et al., 2004), Withania Somnifera (L.) plantlets (Lee et al., 2007). B involves inhibition of cell expansion or division (Appelgren, 1991; Folta et al., 2003; Dougher and Bugbee, 2004), therefore a reduction in B could increase leaf area (LA; Dougher and Bugbee, 2001; Hogewoning et al., 2010a; Hernández and Kubota, 2014), which promotes light interception and dry weight accumulation.

It has been reported that $P_{\mathrm{n}}$ and shoot dry weight could be increased by mixture of $\mathrm{R}$ and $\mathrm{B}$ compared with monochromatic light (Brown et al., 1995; Goins et al., 1997; Ohashi-Kaneko et al., 2006; Hogewoning et al., 2010b; Nanya et al., 2012; Li et al., 2013). However, there are discrepancies for different plants in response to $B$ dose in the background $R$. It has been reported that the optimal R/B ratio for fresh and dry weight accumulation in strawberry plantlet, rapeseed (Brassica napus L.) plantlets in vitro, and cucumber seedlings was 7/3 (Nhut et al., 2003), 1/3 (Li et al., 2013), and 9 (Hernández and Kubota, 2016), respectively.

Lettuce as a fresh salad food is an important vegetable throughout the world because of its fast growth and commercial value, and it is known to be sensitive to light quality as a model crop (Dougher and Bugbee, 2001; Lin et al., 2013). For lettuce,

Abbreviations: $A_{\max }$, photosynthetic capacity; $\mathrm{Ab}$, abaxial surfaces of lettuce; Ad, adaxial surfaces of lettuce; $B$, blue light; $C_{\mathrm{i}}$, intercellular carbon dioxide concentration; Chl, chlorophyll content; Chl/LA, chlorophyll content per leaf area; $F_{\mathrm{s}}$, the light-adapted steady state fluorescence; $\mathrm{FW}$, fresh weight; $F_{\mathrm{v}}{ }^{\prime} / F_{\mathrm{m}}{ }^{\prime}$, the efficiency of excitation capture by open PSII center; $g_{\mathrm{m}}$, apparent mesophyll conductance; $g_{s}$, stomatal conductance; $L_{s}$, stomatal limitation value; LA, leaf area; LED, light-emitting diode; LMA, leaf mass area; $\mathrm{N}$, nitrogen content per unit dry weight; N/LA, nitrogen content per unit LA; NUE, $A_{\max }$ per unit N/LA; $P_{\mathrm{n}}$, photosynthetic rate; $\mathrm{R}$, red light; $\mathrm{R} / \mathrm{B}$ ratio, the ratio of $\mathrm{R}$ to $\mathrm{B}$; VPD, vapor pressure difference; $\alpha$, photochemical efficiency at low light; ФPSII, the effective quantum yield of PSII. addition of $\mathrm{B}$ under $\mathrm{R}$ could inhibit hypocotyl extension and cotyledon elongation (Hoenecke et al., 1992), increase dry weight, LA, and leaf number (Yorio et al., 1998, 2001; Johkan et al., 2010; Wojciechowska et al., 2015). In contrast, it also been reported that greater dry weight and LA under R treatment were observed than those under mixture of R and B treatments (Ohashi-Kaneko et al., 2007; Son and Oh, 2013; Wollaeger and Runkle, 2014). Therefore, the optimal R/B ratio under a combination of red and blue lightemitting diodes (LEDs) is not yet determined. And few studies have been reported about the effects of different $\mathrm{R} / \mathrm{B}$ ratios on leaf photosynthetic performance of lettuce.

The objective of the present study was to determine the effects of different $\mathrm{R} / \mathrm{B}$ ratios on morphology and photosynthetic performance of lettuce by investigating photosynthetic rate, chlorophyll fluorescence, stomatal development, light response curve, and nitrogen content. The results of this study would be used to give guidance on light sources design for lettuce cultivation in a controlled environment.

\section{MATERIALS AND METHODS}

\section{Plant Material and Experimental Setup}

Lettuce (Lactuca sativa L.) seeds were sown in substrate containing a mixture of vermiculite and peat $(3: 1, \mathrm{~V} / \mathrm{V})$, and geminated under $150 \mu \mathrm{mol} \cdot \mathrm{m}^{-2} \cdot \mathrm{s}^{-1}$ irradiance provided by fluorescent lamps (TL-D 36W, Philips) in a controlled environment. After the second leaf was fully expanded, the seedlings were randomly divided into six groups and transferred to six separate hydroponic (Yamasaki lettuce nutrient solution; $\mathrm{pH} \approx 5.8 ; \mathrm{EC} \approx 1.5 \mathrm{mS} \cdot \mathrm{cm}^{-1}$ ) systems in a controlled environment. Air temperature was $24^{\circ} \mathrm{C}$ during photoperiod and $20^{\circ} \mathrm{C}$ during dark period. Photoperiod, relative humidity and $\mathrm{CO}_{2}$ concentration were $16 \mathrm{~h} \cdot \mathrm{d}^{-1}, 60 \%$, and $400 \mu \mathrm{mol} \cdot \mathrm{mol}^{-1}$, respectively. LEDs were equipped with light plates (Dongguan Bio-lighting Sciences and Technology Co. Ltd, China) and power DC supply (PKU-MS605D). Irradiance of R and B was individually controlled by adjusting electric current of power DC supply for each treatment. LEDs provided $\mathrm{R}$ with peak wavelength of $657 \mathrm{~nm}$ and B with peak wavelength of $450 \mathrm{~nm}$. All plants were subjected to $200 \mu \mathrm{mol} \cdot \mathrm{m}^{-2} \cdot \mathrm{s}^{-1}$ irradiance measured by spectrometer (AvaSpec-2048-USB2, the Netherland) at the top of the canopy. Six light quality treatments based on different $R / B$ ratios, were created and labeled as $\mathrm{R}, \mathrm{R} / \mathrm{B}=12, \mathrm{R} / \mathrm{B}=8, \mathrm{R} / \mathrm{B}=4$, $\mathrm{R} / \mathrm{B}=1$, and $\mathrm{B}$. Lettuce plants were grown for 30 days after transplanting before harvest. All the treatments were repeated twice.

\section{Chlorophyll Concentration}

Samples were excised from the leaves of 10 plants at a similar position for each treatment. Leaves were weighed out in 0.1$0.2 \mathrm{~g}$ (fresh weight, FW). The extractions were performed using $10 \mathrm{ml}(\mathrm{V})$ of $80 \%$ acetone until the leaf turned white. The optical density was measured with UV-1800 spectrophotometer (Shimadzu, Japan) at 663nm (OD663) and at $645 \mathrm{~nm}$ (OD645) for chlorophyll a (Chl a) and chlorophyll b ( Chl b). The chlorophyll concentrations (Chl) were determined using (Lichtenthaler and 
Wellburn, 1983):

$$
\begin{aligned}
& \operatorname{Chla}\left(m g \cdot g^{-1}\right)=\frac{\left(12.72 \times O D_{663}-2.59 \times O D_{645}\right) \cdot V}{1000 \times W} \\
& \operatorname{Chlb}\left(m g \cdot g^{-1}\right)=\frac{\left(22.88 \times O D_{645}-4.67 \times O D_{663}\right) \cdot V}{1000 \times W}
\end{aligned}
$$

Where $V$ is the total volume of acetone extract $(\mathrm{ml})$ and $W$ is FW (g) of sample.

\section{Photosynthetic Characteristics and Chlorophyll Fluorescence}

Photosynthetic light response curves and photosynthetic characteristics were measured on fully expanded second leaves of four plants from each treatment using the method of $\mathrm{Li}$ et al. (2014) with slight modification. The light response curve was measured by using 10 light intensities in the range from 0 to $1200 \mu \mathrm{mol} \cdot \mathrm{m}^{-2} \cdot \mathrm{s}^{-1}$. The starting light intensity was $200 \mu \mathrm{mol} \cdot \mathrm{m}^{-2} \cdot \mathrm{s}^{-1}$, followed by $100,50,25,0,400,600,800$, 1000 , and $1200 \mu \mathrm{mol} \cdot \mathrm{m}^{-2} \cdot \mathrm{s}^{-1}$. Measurements of photosynthetic light response curves and photosynthetic characteristics were all performed on a single leaf exposed to light source $(10 \%$ B, 90\% R) provided by a portable photosynthesis system (Li-6400, Li-Cor Inc., Lincoln, NE, USA). Leaf temperature and $\mathrm{CO}_{2}$ concentration in the leaf chamber were $24^{\circ} \mathrm{C}$ and $400 \mu \mathrm{mol} \cdot \mathrm{mol}^{-1}$, respectively. The VPD in the leaf chamber was maintained at $1.1 \mathrm{kPa}$. Data were taken when $P_{\mathrm{n}}$ reached steady state at each light intensity level. Samples from each treatment were measured in the order of $R, R / B=12, R / B=8, R / B=4$, $\mathrm{R} / \mathrm{B}=1$, and $\mathrm{B}$; hereafter the same measurements were repeated three times. When light response curves were measured, data obtained at light intensity of $200 \mu \mathrm{mol} \cdot \mathrm{m}^{-2} \cdot \mathrm{s}^{-1}$ were considered as photosynthetic characteristics.

Chlorophyll fluorescence was also measured on the fully expanded second leaves of four plants from each treatment by a portable photosynthesis system (Li-6400, Li-Cor Inc., Lincoln, $\mathrm{NE}$, USA). Saturating flashes $\left(8000 \mu \mathrm{mol} \cdot \mathrm{m}^{-2} \cdot \mathrm{s}^{-1}\right)$ were applied to determine the maximum fluorescence yield during actinic light $\left(F_{\mathrm{m}}{ }^{\prime}\right)$. The effective quantum yield of PSII ( $\Phi$ PSII) was calculated: ФPSII $=\left(F_{\mathrm{m}}{ }^{\prime}-F_{\mathrm{s}}\right) / F_{\mathrm{m}}{ }^{\prime}$ (Genty et al., 1989). $F_{\mathrm{s}}$ is the light-adapted steady state fluorescence.

\section{Stomata Characteristic and Leaf Gas Exchange}

Samples were excised from the fully expanded second leaves of four plants at a similar position for each treatment. To observe the stomata, transparent nail polish was smeared on the surface of the leaves. The slides made by the leaf epidermal fingerprint with the transplant nail polish method (Zeng et al., 2008) were observed by optical microscope (Olympus DP71, Olympus Inc., Japan). The length, width and density of stomata were measured with Image-Pro Express software (Olympus Inc., Japan).

Stomatal limitation value $\left(L_{\mathrm{s}}\right)$ was calculated as $1-C_{\mathrm{i}} / C_{\mathrm{a}}$ (Farquhar and Sharkey, 1982), $C_{\mathrm{a}}$ was $\mathrm{CO}_{2}$ concentration in leaf chamber. Apparent mesophyll conductance $\left(g_{\mathrm{m}}\right)$ was calculated as $P_{\mathrm{n}} / C_{\mathrm{i}}$ (Fischer et al., 1998). $C_{\mathrm{i}}$ was intercellular $\mathrm{CO}_{2}$ concentration.

\section{LMA, Sucrose, Starch, Carbon, and Nitrogen Content}

The leaf mass area (LMA) was calculated using (Hernández and Kubota, 2016):

$$
\text { LMA }\left(\mathrm{g} \cdot \mathrm{cm}^{-2}\right)=\frac{\text { leaf dry weight }}{\text { leaf area }}
$$

Samples were excised from the leaves of four plants for each treatment before the end of dark period. Total sugar was extracted using the method of Li et al. (2013). The sucrose concentration was determined using the resorcinol method and measured at $480 \mathrm{~nm}$. Extraction of starch was obtained by the method of Takahashi et al. (1995). Starch content was calculated by converting glucose to starch equivalents using a factor of 0.9 (Li et al., 2010). The glucose concentration was determined by using the sulfuric acid anthrone method and measured at $620 \mathrm{~nm}$. Leaf nitrogen content was determined with element analyzer (Isoprime GC5, Italy).

\section{Statistical Analysis}

The fitting parameters of light response curve, including photosynthetic capacity $\left(A_{\max }\right)$, dark respiration rate $\left(R_{\mathrm{d}}\right)$ and photochemical efficiency at low light $(\alpha)$, were fitted with a non-rectangular hyperbola (Thornley, 1976) using the non-linear fitting procedure ARSIN in SAS (SAS Institute Inc. 9.1, Cary, NC, USA).

All measurements were based on four replicate plants. Statistical analysis was subjected to one-way analysis of using variance ANOVA, and significant differences between the means were tested using Duncan's multiple range test at 95\% confidence.

\section{RESULTS}

\section{Leaf Photosynthesis and $L_{\mathrm{s}}$}

The same trend was observed on results of the repeated experiments. Thus, one dataset of the repeated experiments was shown in this study. $P_{\mathrm{n}}$ differed significantly under different $\mathrm{R} / \mathrm{B}$ ratios treatments (Figure 1A). Decreased R/B ratio led to increasing $P_{\mathrm{n}}$, except $\mathrm{B}$. Similar trends were observed in $C_{\mathrm{i}}$, $g_{\mathrm{m}}$ and stomatal conductance $\left(g_{\mathrm{s}}\right)$ in the change of $\mathrm{R} / \mathrm{B}$ ratio (Figures 1B,D and 4). $P_{\mathrm{n}}$ under $\mathrm{B}$ treatment did not follow the trend of $P_{\mathrm{n}}$ increasing with decreasing $\mathrm{R} / \mathrm{B}$ ratio, which was $7.6 \%$ lower compared to that under $\mathrm{R} / \mathrm{B}=1$ treatment. $P_{\mathrm{n}}$ under $\mathrm{B}$ and $\mathrm{R} / \mathrm{B}=1$ treatments was 53.2 and $74.0 \%$ higher than that under $\mathrm{R}$ treatment, respectively. However, $L_{\mathrm{s}}$ had the opposite trend with decreasing R/B ratio (Figure $1 \mathrm{C}$ ). $P_{\mathrm{n}}$ correlated positively with $g_{\mathrm{m}}$ and $g_{\mathrm{s}}$ and inversely with $L_{\mathrm{s}}$ (Figure 2 ).

\section{Growth and Morphology}

Growth and morphology in lettuce showed significant difference under different R/B ratios treatments (Table 1). Shoot dry weight gradually increased with increasing $\mathrm{R} / \mathrm{B}$ ratio with the greatest 

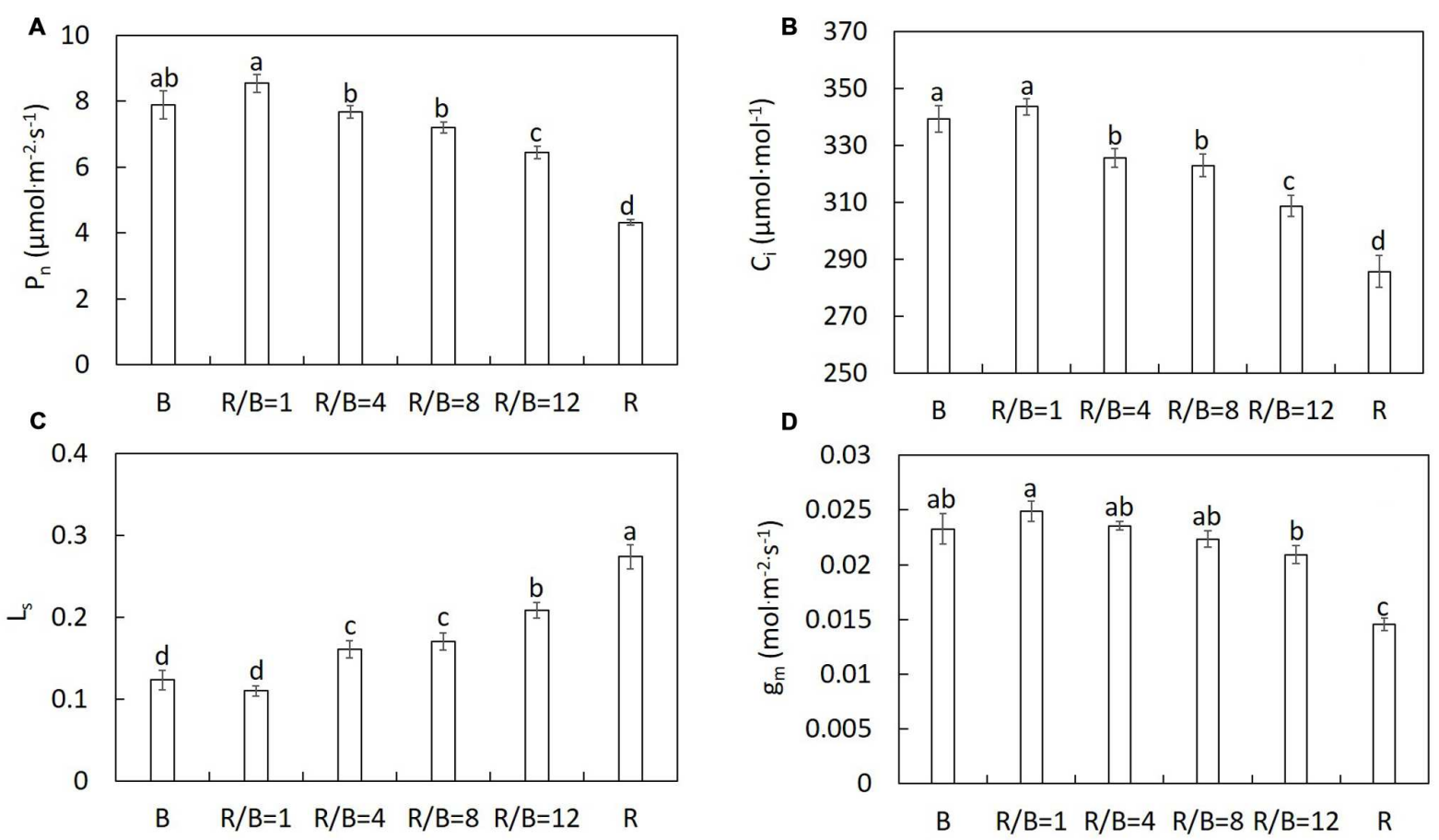

FIGURE 1 | The effect of different R/B ratios on $P_{n}(A), C_{i}(B), L_{s}(C)$, and $g_{m}(D)$ at the growth irradiance of lettuce. Values were the means of four replicates with standard errors shown by vertical bars. Different letters indicate significant differences using the Duncan's Multiple Range Test $(p<0.05 ; n=4)$.
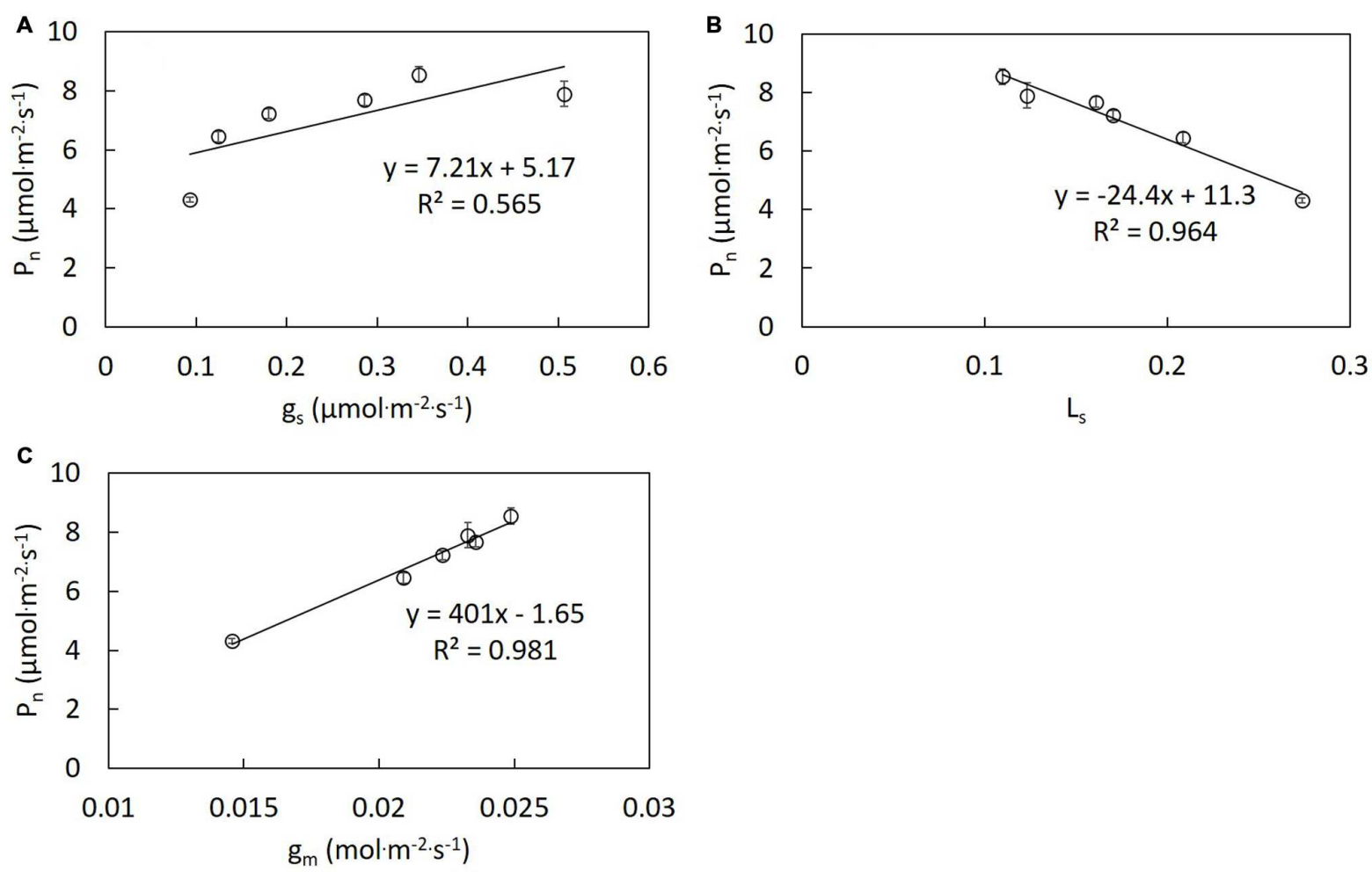

FIGURE 2 | Correlation analysis between $\boldsymbol{P}_{\mathrm{n}}$ and $\boldsymbol{g}_{\mathrm{s}}(\mathrm{A}), \boldsymbol{L}_{\mathrm{s}}(\mathrm{B})$, and $\boldsymbol{g}_{\mathrm{m}}(\mathrm{C})$ of lettuce grown under different $\mathrm{R} / \mathrm{B}$ ratios treatments. Values were the means of four replicates with standard errors shown by vertical bars. Different letters indicate significant differences using the Duncan's Multiple Range Test $(p<0.05$; $n=4$ ). 
TABLE 1 | Effects of different R/B ratios on shoot dry weight, leaf number, Chl, Chl a/b, LA, Chl per leaf area (Chl/LA) and LMA.

\begin{tabular}{|c|c|c|c|c|c|c|}
\hline $\mathrm{R} / \mathrm{B}$ ratio & B & $R / B=1$ & $\mathrm{R} / \mathrm{B}=4$ & $R / B=8$ & $R / B=12$ & $\mathbf{R}$ \\
\hline Shoot dry weight (g) & $0.95^{\mathrm{c}}$ & $1.04^{\mathrm{c}}$ & $1.37^{b}$ & $1.67^{\mathrm{a}}$ & $1.83^{\mathrm{a}}$ & $1.80^{\mathrm{a}}$ \\
\hline Leaf number & $20^{c}$ & $22^{c}$ & $25^{b}$ & $30^{a}$ & $28^{\mathrm{ab}}$ & $26^{b}$ \\
\hline $\mathrm{Chl}\left(\mathrm{mg} \cdot \mathrm{g}^{-1} \mathrm{FW}\right)$ & $0.85^{\mathrm{a}}$ & $0.77^{\mathrm{ab}}$ & $0.81^{\mathrm{a}}$ & $0.74^{\mathrm{ab}}$ & $0.69^{b c}$ & $0.60^{c}$ \\
\hline Chl a/b & $3.20^{a b}$ & $3.15^{\mathrm{ab}}$ & $3.28^{\mathrm{a}}$ & $3.18^{a b}$ & $3.00^{\mathrm{bc}}$ & $2.83^{\mathrm{C}}$ \\
\hline $\mathrm{LA}\left(\mathrm{cm}^{2}\right)$ & $545^{\mathrm{C}}$ & $597^{\mathrm{C}}$ & $771^{\mathrm{b}}$ & $898^{a}$ & $956^{a}$ & $950^{a}$ \\
\hline $\mathrm{Chl} / \mathrm{LA}\left(\mathrm{g} \cdot \mathrm{m}^{-2}\right)$ & $0.27^{\mathrm{bc}}$ & $0.30^{\mathrm{ab}}$ & $0.32^{a}$ & $0.32^{a}$ & $0.30^{\mathrm{ab}}$ & $0.24^{c}$ \\
\hline LMA $\left(g \cdot m^{-2}\right)$ & $17.3^{\mathrm{a}}$ & $17.4^{\mathrm{a}}$ & $17.8^{a}$ & $18.7^{\mathrm{a}}$ & $18.8^{a}$ & $19.0^{a}$ \\
\hline
\end{tabular}

Different letters indicate significant differences using the Duncan's Multiple Range Test $(p<0.05 ; n=4)$.

value under $\mathrm{R} / \mathrm{B}=12$ treatment, and no significant difference was observed between $\mathrm{R} / \mathrm{B}=12$ and $\mathrm{R}$ treatments. Shoot dry weight under $\mathrm{B}$ treatment was 48.1 and $47.2 \%$ lower in comparison with those under R/B = 12 and $\mathrm{R}$ treatments, respectively. Similar trends were observed for plants in leaf number, LA and LMA. For LMA, there was no significant difference among plants cultured under the six treatments. Chl increased with decreasing $\mathrm{R} / \mathrm{B}$ ratio. Addition of $\mathrm{B}$ increased $\mathrm{Chl} \mathrm{a} / \mathrm{b}$ of lettuce leaves compared to that of R-grown leaves with the lowest value. Chlorophyll content per leaf area (Chl/LA) under mixture of $\mathrm{R}$ and $\mathrm{B}$ treatments was higher than those grown under monochromatic R or B treatment.

\section{Photosynthetic Light Response Curves and Fluorescence Characteristics}

Different $\mathrm{R} / \mathrm{B}$ ratios significantly affected $P_{\mathrm{n}}$ in the change of irradiance. The differences in $P_{\mathrm{n}}$ between $\mathrm{R}$ and other treatments became increasingly greater with the increase of irradiance. The enhanced effect of decreasing $\mathrm{R} / \mathrm{B}$ ratio on $P_{\mathrm{n}}$ was similar with that caused by increasing irradiance (Figure 3). For the fitting parameters of photosynthetic light response curve, a reduction in $\mathrm{R} / \mathrm{B}$ ratio led to increasing $A_{\max }$, except for $\mathrm{B}$ treatment (Table 2). $A_{\max }$ under $\mathrm{B}$ and $\mathrm{R} / \mathrm{B}=1$ treatments was 82.7 and $97.8 \%$ higher than that under $\mathrm{R}$ treatment, respectively. $R_{\mathrm{d}}$ was the highest under $\mathrm{R} / \mathrm{B}=8$ treatment and the lowest under $\mathrm{B}$ treatment. Compared with monochromatic light treatments, $\alpha$ was higher under mixture of $\mathrm{R}$ and $\mathrm{B}$ treatments, with the maximum value under $\mathrm{R} / \mathrm{B}=12$ treatment.

Plants grown under $\mathrm{B}$ treatment had a lower efficiency of excitation capture by open PSII center $\left(\mathrm{F}_{\mathrm{v}}{ }^{\prime} / \mathrm{F}_{\mathrm{m}}{ }^{\prime}\right)$ compared to the other treatments. Similar result was observed in $\Phi$ PSII (Table 3).

\section{Stomatal Characteristics}

$g_{\mathrm{s}}$ of lettuce leaves had been significantly altered after being exposed to different $\mathrm{R} / \mathrm{B}$ ratios in the change of irradiance ranging

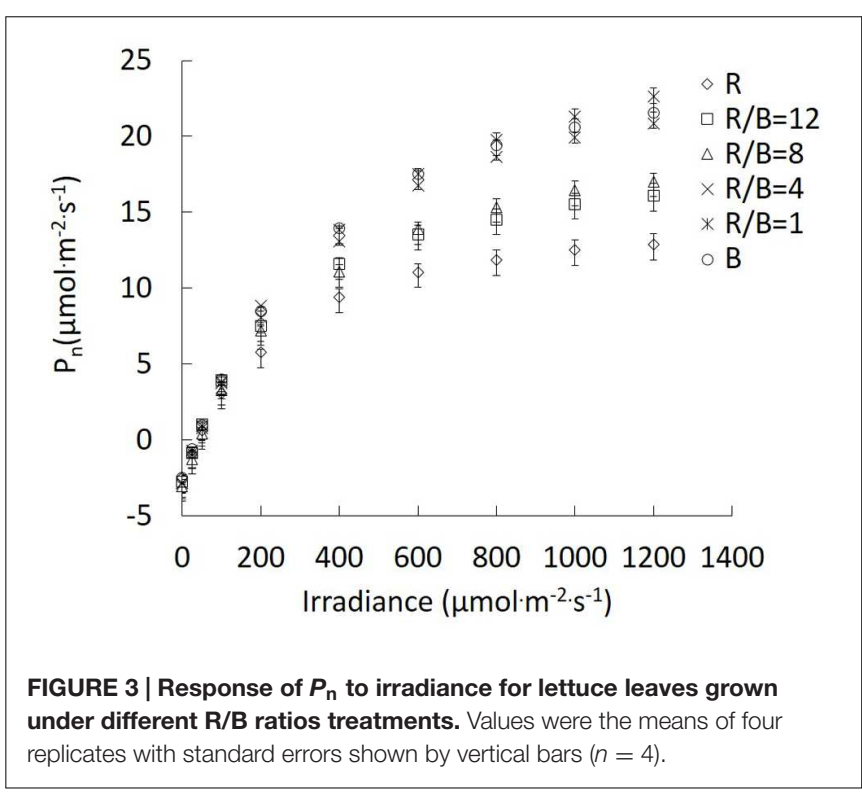

from 0 to $200 \mu \mathrm{mol} \cdot \mathrm{m}^{-2} \cdot \mathrm{s}^{-1} \cdot g_{\mathrm{s}}$ increased with increasing irradiance under $\mathrm{B}, \mathrm{R} / \mathrm{B}=1, \mathrm{R} / \mathrm{B}=4, \mathrm{R} / \mathrm{B}=8$, and $\mathrm{R} / \mathrm{B}=12$ treatments, except for $\mathrm{R}$ treatment. $g_{\mathrm{s}}$ under $\mathrm{R}$ treatment was almost unresponsive to increasing irradiance. The highest $g_{\mathrm{s}}$ was observed under $\mathrm{B}$ treatments, followed by $\mathrm{R} / \mathrm{B}=1, \mathrm{R} / \mathrm{B}=4$, $\mathrm{R} / \mathrm{B}=8$, and $\mathrm{R} / \mathrm{B}=12$, with the lowest value under $\mathrm{R}$ treatment at the same measured irradiance (Figure 4). The effect of decreasing $\mathrm{R} / \mathrm{B}$ ratio on $g_{\mathrm{s}}$ was similar with that caused by increasing irradiance.

As shown in Table 4, stomatal development differed greatly under different $\mathrm{R} / \mathrm{B}$ ratios treatments at the growth irradiance. Decreased R/B ratio gradually caused higher stomatal density on the abaxial and adaxial surfaces. Leaves under B treatment did not follow the trend of stomatal density increasing with

TABLE 2 | Effects of different R/B ratios on the fitting parameters of photosynthetic light response curve, including $\boldsymbol{A}_{\text {max }}, \boldsymbol{R}_{\mathrm{d}}$ and $\alpha$.

\begin{tabular}{|c|c|c|c|c|c|c|}
\hline $\mathrm{R} / \mathrm{B}$ ratio & B & $R / B=1$ & $\mathrm{R} / \mathrm{B}=4$ & $R / B=8$ & $R / B=12$ & $\mathbf{R}$ \\
\hline$A_{\max }\left(\mu \mathrm{mol} \mathrm{CO} \mathrm{CO}_{2} \cdot \mathrm{m}^{-2} \cdot \mathrm{s}^{-1}\right)$ & $27.6^{b}$ & $31.3^{\mathrm{a}}$ & $29.7^{\mathrm{ab}}$ & $23.8^{c}$ & $20.7^{d}$ & $18.0^{\mathrm{e}}$ \\
\hline $\mathrm{R}_{\mathrm{d}}\left(\mu \mathrm{mol} \mathrm{CO}_{2} \cdot \mathrm{m}^{-2} \cdot \mathrm{s}^{-1}\right)$ & $2.3^{\mathrm{C}}$ & $2.7^{b}$ & $2.8^{b}$ & $3.3^{\mathrm{a}}$ & $2.7^{\mathrm{b}}$ & $2.6^{b c}$ \\
\hline$\alpha\left(\mu \mathrm{mol}\right.$ photons $\left.\cdot \mathrm{m}^{-2} \cdot \mathrm{s}^{-1}\right)$ & $0.082^{b}$ & $0.086^{a b}$ & $0.114^{a b}$ & $0.108^{a b}$ & $0.117^{a}$ & $0.084^{b}$ \\
\hline
\end{tabular}

Different letters indicate significant difference using the Duncan's Multiple Range Test $(p<0.05 ; n=4)$. 
TABLE 3 | Effects of different R/B ratios on the efficiency of excitation capture by open PSII center $\left(F_{\mathrm{v}}{ }^{\prime} / F_{\mathrm{m}}{ }^{\prime}\right)$, and $\Phi P S I I$.

\begin{tabular}{|c|c|c|c|c|c|c|}
\hline $\mathrm{R} / \mathrm{B}$ ratio & B & $R / B=1$ & $\mathrm{R} / \mathrm{B}=4$ & $R / B=8$ & $R / B=12$ & $\mathbf{R}$ \\
\hline$F_{\mathrm{v}}^{\prime} / F_{\mathrm{m}}^{\prime}$ & $0.69^{b}$ & $0.76^{a}$ & $0.76^{a}$ & $0.76^{a}$ & $0.77^{\mathrm{a}}$ & $0.77^{a}$ \\
\hline ФPSII & $0.62^{b}$ & $0.67^{a}$ & $0.67^{a}$ & $0.67^{a}$ & $0.68^{a}$ & $0.68^{a}$ \\
\hline
\end{tabular}

Different letters indicate significant difference using the Duncan's Multiple Range Test $(p<0.05 ; n=4)$.

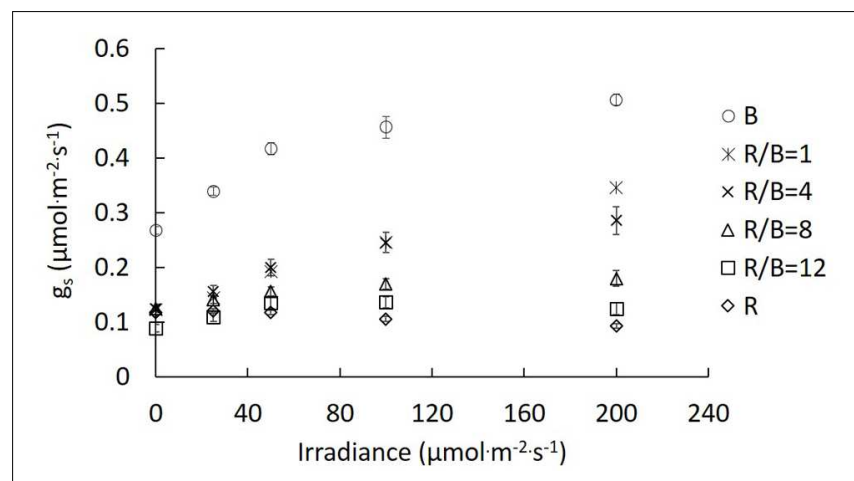

FIGURE 4 | Response of $\boldsymbol{g}_{\mathrm{s}}$ to irradiance for lettuce leaves grown under different $\mathbf{R} / \mathbf{B}$ ratios. Values were the means of four replicates with standard errors shown by vertical bars $(n=4)$.

decreasing R/B ratio, which were 26 and $42 \%$ lower than $\mathrm{R} / \mathrm{B}=1$ treatment on the abaxial and adaxial surfaces, respectively. Stomatal length on the abaxial and adaxial surfaces increased with increasing $\mathrm{R} / \mathrm{B}$ ratio under mixture of $\mathrm{R}$ and $\mathrm{B}$ treatments but with no significant differences, which were significantly higher than those under monochromatic $\mathrm{R}$ or $\mathrm{B}$ treatment. There were no significant differences among stomatal widths on the abaxial and adaxial surfaces of plants cultured under the six treatments. Stomatal pore length and pore width on the abaxial surface under $\mathrm{R}$ and $\mathrm{B}$ treatments were lower than those under the other treatments. Stomatal pore length and pore width on the adaxial surface increased with increasing $\mathrm{R} / \mathrm{B}$ ratio under mixture of $\mathrm{R}$ and $\mathrm{B}$ treatments, but were slightly lower under $\mathrm{R}$ treatment. These results indicated that an addition of $\mathrm{B}$ under background $\mathrm{R}$ could increase stomatal density and stomatal aperture compared with R.

\section{NUE, Nitrogen and Carbohydrate Content}

The ratio of $A_{\max }$ to nitrogen content per LA (NUE) increased with decreasing $\mathrm{R} / \mathrm{B}$ ratio with the highest value under $\mathrm{R} / \mathrm{B}=1$ treatment, but was significantly lower under $\mathrm{B}$ treatment (Figure 5). NUE under $\mathrm{B}$ and $\mathrm{R} / \mathrm{B}=1$ treatments was 57 and $76 \%$ higher than that under $\mathrm{R}$ treatment, respectively. The accumulation of sucrose under $\mathrm{R}$ and $\mathrm{R} / \mathrm{B}=12$ treatments were higher than those under $\mathrm{R} / \mathrm{B}=8, \mathrm{R} / \mathrm{B}=4, \mathrm{R} / \mathrm{B}=1$, and $\mathrm{B}$ treatments. The accumulation of starch was the highest under $\mathrm{R}$ treatment and the lowest under $\mathrm{B}$ treatment (Table 5).

\section{DISCUSSION}

\section{Additional B had a Greater Impact on $\boldsymbol{P}_{\mathbf{n}}$ and $\boldsymbol{A}_{\max }$ by Combination of $R$}

Combination of $\mathrm{R}$ and $\mathrm{B}$ has been proved to be effective in driving photosynthesis. As shown in Figure 1A and Table 2, increasing $P_{\mathrm{n}}$ and $A_{\max }$ with decreasing $\mathrm{R} / \mathrm{B}$ ratio until 1 has been observed in the present study. This result indicated that photosynthetic performance of lettuce plant could be efficiently improved by increasing B fraction. The same trends have been reported in rice (Matsuda et al., 2004), and cucumber seedling (Hogewoning et al., 2010b; Hernández and Kubota, 2016). For example, Matsuda et al. (2004) reported that $P_{\mathrm{n}}$ in rice plants grown under $\mathrm{R} / \mathrm{B}=4$ treatment increased 88 and $53 \%$ than those grown under $\mathrm{R}$ treatment at the measured irradiance of 1600 and $200 \mu \mathrm{mol} \cdot \mathrm{m}^{-2} \cdot \mathrm{s}^{-1}$, respectively. Hogewoning et al. (2010b) tested the effect of different $B$ fractions on leaf photosynthesis of cucumber seedlings. They found that $P_{\mathrm{n}}$ and $A_{\max }$ increased with increasing $B$ fraction up to $50 \%$ (irradiance: $100 \mu \mathrm{mol} \cdot \mathrm{m}^{-2} \cdot \mathrm{s}^{-1}$; photoperiod: $\left.16 \mathrm{~h} \cdot \mathrm{d}^{-1}\right)$. This result was supported by analyzing

TABLE 4 | Effects of different R/B ratios on leaf stomata development. Ab and Ad represented abaxial and adaxial surfaces of lettuce leaves.

\begin{tabular}{|c|c|c|c|c|c|c|c|c|c|c|}
\hline $\mathrm{R} / \mathrm{B}$ ratio & \multicolumn{2}{|c|}{ Stomatal length $(\mu \mathrm{m})$} & \multicolumn{2}{|c|}{ Stomatal width $(\mu \mathrm{m})$} & \multicolumn{2}{|c|}{ Pore length $(\mu \mathrm{m})$} & \multicolumn{2}{|c|}{ Pore width $(\mu \mathrm{m})$} & \multicolumn{2}{|c|}{ Stomatal density (stomata $\mathrm{mm}^{-2}$ ) } \\
\hline$R / B=1$ & $29.4^{\mathrm{ab}}$ & $29.8^{\mathrm{b}}$ & $21.8^{\mathrm{a}}$ & $21.9^{\mathrm{a}}$ & $9.8^{\mathrm{ab}}$ & $7.0^{\mathrm{bc}}$ & $3.8^{\mathrm{a}}$ & $2.4^{\mathrm{b}}$ & $363^{a}$ & $434^{a}$ \\
\hline $\mathrm{R} / \mathrm{B}=4$ & $29.8^{\mathrm{ab}}$ & $30.9^{\mathrm{ab}}$ & $21.9^{\mathrm{a}}$ & $22.0^{\mathrm{a}}$ & $10.0^{\mathrm{ab}}$ & $7.1^{\mathrm{bc}}$ & $4.1^{\mathrm{a}}$ & $3.1^{\mathrm{ab}}$ & $283^{b}$ & $320^{b}$ \\
\hline $\mathrm{R} / \mathrm{B}=8$ & $30.0^{\mathrm{ab}}$ & $31.2^{\mathrm{ab}}$ & $22.1^{\mathrm{a}}$ & $22.1^{\mathrm{a}}$ & $10.6^{\mathrm{a}}$ & $8.4^{\mathrm{ab}}$ & $3.9^{a}$ & $3.2^{\mathrm{a}}$ & $257^{\mathrm{bc}}$ & $278^{\mathrm{bc}}$ \\
\hline
\end{tabular}

Data were means of 40 fields of view for four samples from each treatment. Different letters indicate significant difference using the Duncan's Multiple Range Test ( $p<0.05$; $n=4)$. 


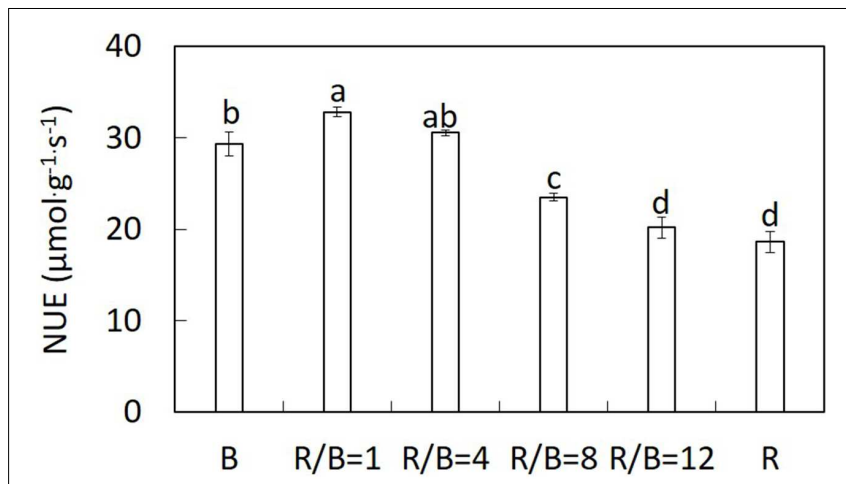

FIGURE 5 | Effect of different R/B ratios on the ratio of leaf $\boldsymbol{A}_{\max }$ to nitrogen content per LA (NUE). Values were the means of four replicates with standard errors shown by vertical bars. Different letters indicate significant difference using the Duncan's Multiple Range Test $(p<0.05 ; n=4)$.

the effects of different $\mathrm{R} / \mathrm{B}$ ratios on $\mathrm{Chl}$, stomatal characteristics, chlorophyll fluorescence, nitrogen content and carbohydrate content.

Chlorophyll is the pigment used for absorbing red and blue light, and $\mathrm{Chl} \mathrm{a}$ is the molecule that makes photosynthesis possible (Johkan et al., 2010). An increase in Chl with decreasing $\mathrm{R} / \mathrm{B}$ ratio was shown in Table 1. A higher Chl could increase light absorption, which was beneficial for $P_{\mathrm{n}}$. Earlier studies have shown that B-deficiency was adverse to chlorophyll biosynthesis in wheat seedling (Tripathy and Brown, 1995), spinach (Matsuda et al., 2008), Rosa $\times$ hybrida (Terfa et al., 2013), and cucumber seedling (Hogewoning et al., 2010b; Hernández and Kubota, 2016). Plants grown under mixture of $\mathrm{R}$ and $\mathrm{B}$ or $\mathrm{B}$ treatments had a higher $\mathrm{Chl} \mathrm{a} / \mathrm{b}$ compared with $\mathrm{R}$ treatment (Table 1). A higher $\mathrm{Chl} \mathrm{a/b}$ indicates a high lightadapted photosynthetic apparatus with less Chl b containing light-harvesting antennae, and thereby a higher capacity for electron transport and more Calvin cycle enzymes on a Chl basis (Evans, 1988). Therefore, plants grown under mixture of $\mathrm{R}$ and $\mathrm{B}$ or $\mathrm{B}$ treatments had higher $P_{\mathrm{n}}$ on a Chl basis in the current study.

$\mathrm{B}$ is perceived directly by phototropins and activates a signaling cascade that results in fast stomatal opening under background R (Shimazaki et al., 2007). Leaves exhibited higher $g_{\mathrm{s}}$ with decreasing $\mathrm{R} / \mathrm{B}$ ratio. The lowest $P_{\mathrm{n}}$ and $A_{\max }$ under $\mathrm{R}$ treatment were attributed to unresponsive $g_{\mathrm{s}}$ to increasing irradiance (Figure 4) and stomatal limitation. This was confirmed by the highest $L_{\mathrm{s}}$ under R treatment (Figure 1C). Similar result was found by Hogewoning et al. (2010b), who reported that $\mathrm{R}$ alone resulted in a more restricted diffusion into leaf and lower $\mathrm{C}_{\mathrm{i}} \mathrm{C}_{\mathrm{a}}{ }^{-1}$ in cucumber seedlings compared with $\mathrm{R}$ supplemented with B. Correlation analysis between $P_{\mathrm{n}}$ and $g_{\mathrm{s}}, g_{\mathrm{m}}$ and $L_{\mathrm{s}}$ indicated that an increase in $P_{\mathrm{n}}$ with decreasing $\mathrm{R} / \mathrm{B}$ ratio was mainly due to increased $g_{\mathrm{m}}$ and $g_{\mathrm{s}}$ and decreased stomatal limitation by decreasing R/B ratio (Figure 2). Although single stomatal size and stomatal pore area at the growth irradiation had a slight decrease with decreasing $\mathrm{R} / \mathrm{B}$ ratio, stomatal density appeared to significantly increase (Table 4), resulting in an increase in $g_{s}$. These results suggested that there was a direct effect of B fraction on stomatal development, further affecting photosynthesis.

$\mathrm{R}$ is considered as the most efficient wavelength for photosynthesis. McCree (1972) reported that the relative quantum efficiency of $\mathrm{R}(600-700 \mathrm{~nm})$ was higher than that of B (400-500 nm), because fractional B was absorbed by flavonoids in vacuoles and/or pigments (anthocyanins) without function for photosynthesis in chloroplasts or less efficient in transferring energy to the reaction centers. However, it should be noted that plants grown under $\mathrm{R}$ treatment had the lowest $P_{\mathrm{n}}$ and $A_{\max }$ from all the treatments (Figure 1A and Table 2). A lower $\alpha$ under $\mathrm{R}$ treatment indicated that there were problems in photosystem. Similar result was also reported by Hogewoning et al. (2010b), who found that in cucumber seedlings B-deficiency led to leaf photosynthetic machinery dysfunction, resulting in lower $P_{\mathrm{n}}$ and $A_{\text {max }}$. Miao et al. (2016) also reported that $\mathrm{R}$ alone could induce suboptimal activity of photosystems and inhibit electron transport from PSII donor side to PSI. Plants grown under B treatment also had a slight decrease in $P_{\mathrm{n}}$ in comparison with plants grown under $\mathrm{R} / \mathrm{B}=1$ treatment. For B-grown leaves, higher $g_{s}$ and $C_{\mathrm{i}}$ could not be limiting factors for slight decrease in $P_{\mathrm{n}}$. The possible explanation was imbalance of energy allocation between two photosystems (Tennessen et al., 1994). This was verified by lower $F_{\mathrm{v}}{ }^{\prime} / F_{\mathrm{m}}{ }^{\prime}$ and ФPSII in plants subjected to monochromatic B (Table 3).

NUE increased with decreasing R/B ratio until 1 (Figure 5), indicating that $\mathrm{N}$ availability didn't limit the exertion of photosynthetic capacity (Hogewoning et al., 2010b). However, accumulation of carbohydrate in leaves should be an impact factor for $P_{\mathrm{n}}$. Higher starch content, along with a lower $P_{\mathrm{n}}$ under $\mathrm{R}$ treatment was shown than other treatments (Table 5). This result was similar with previous studies showed that the increase of sucrose and starch content under $\mathrm{R}$ treatment resulting from restriction of export of photosynthetic products out of the leaves (Sæbø et al., 1995; Li et al., 2013), which was not conducive to photosynthesis (Bondada and Syvertsen, 2003). Down-regulated $P_{\mathrm{n}}$ by carbohydrate accumulation in source leaves was a response to limited sink demand (Franck et al., 2006).

TABLE 5 | Effects of different R/B ratios on sucrose and starch content.

\begin{tabular}{llllll}
\hline $\mathbf{R} / \mathbf{B}$ ratios & $\mathbf{B}$ & $\mathbf{R} / \mathbf{B}=\mathbf{1}$ & $\mathbf{R} / \mathbf{B}=\mathbf{4}$ & $\mathbf{R} / \mathbf{B}=\mathbf{8}$ & $\mathbf{R} / \mathbf{B}=\mathbf{1 2}$ \\
\hline Sucrose $\left(\mathrm{mg} \cdot \mathrm{g}^{-1}\right)$ & $0.37^{\mathrm{b}}$ & $0.34^{\mathrm{b}}$ & $0.38^{\mathrm{b}}$ & $0.36^{\mathrm{b}}$ & $0.53^{\mathrm{a}}$ \\
Starch $\left(\mathrm{mg} \cdot \mathrm{g}^{-1}\right)$ & $0.10^{\mathrm{d}}$ & $0.10^{\mathrm{d}}$ & $0.13^{\mathrm{c}}$ & $0.16^{\mathrm{ab}}$ & $0.50^{\mathrm{a}}$ \\
\hline
\end{tabular}

Different letters indicate significant difference by the Duncan's Multiple Range Test $(p<0.05 ; n=4)$. 


\section{Conflicting Effects on Growth and $\boldsymbol{P}_{\mathrm{n}}$ Under Different R/B Ratios}

As shown in Table $\mathbf{1}$ and Figure 1A, an increase in shoot dry weight, LA and leaf number with increasing $\mathrm{R} / \mathrm{B}$ ratio was observed, while opposite trend was shown in $P_{\mathrm{n}}$. Similar results has been reported in previous studies in cucumber seedlings (Hernández and Kubota, 2014, 2016). Hernández and Kubota (2016) found that shoot dry weight decreased with increasing B fraction ranging from 10 to $75 \%$, along with decreased LA and increased $P_{\mathrm{n}}$. Hernández and Kubota (2014) reported that cucumber seedlings showed a reduction in shoot dry weight, leaf number, and LA with an increase of B fraction and no significant difference for $P_{\mathrm{n}}$ in a greenhouse with supplemental LED lighting $\left(5.2 \pm 1.2 \mathrm{mmol} \cdot \mathrm{m}^{-2} \cdot \mathrm{s}^{-1}\right)$. One of the possible explanations for this result was that shoot dry weight accumulation of lettuce plant was determined not only by $P_{\mathrm{n}}$, but also other related factors, such as LA, leaf number. Furthermore, $P_{\mathrm{n}}$ measured for single leaf cannot represent $P_{\mathrm{n}}$ of entire canopy and/or whole plant (Yorio et al., 2001). Instead, variation in LA was much more efficient in determinant of variation for plant growth rate than variation in $P_{\mathrm{n}}$ before the canopy achieves full light interception (Gifford and Jenkins, 1981). Hence, compared with $\mathrm{R} / \mathrm{B}=12$ treatment, although $P_{\mathrm{n}}$ under $\mathrm{B}, \mathrm{R} / \mathrm{B}=1, \mathrm{R} / \mathrm{B}=4$, and $\mathrm{R} / \mathrm{B}=8$ treatments was $12-32 \%$ higher, 6-43\% (except for higher leaf number under $\mathrm{R} / \mathrm{B}=8$ treatment) reduction in LA and $11-29 \%$ decline in leaf number under $B, R / B=1$, $\mathrm{R} / \mathrm{B}=4$, and $\mathrm{R} / \mathrm{B}=8$ treatments resulted in decreasing shoot dry weight accumulation with decreasing $\mathrm{R} / \mathrm{B}$ ratio. Another possible explanation for increasing shoot dry weight with increasing $\mathrm{R} / \mathrm{B}$ ratio was due to the fact that plant exhibited greater puffiness with loose plant structure, induced by elongation of stem and leaf petiole with increasing $\mathrm{R}$, leading to much more photosynthetic active radiation to be captured for growth.

Decreasing LA with decreasing $\mathrm{R} / \mathrm{B}$ ratio was similar to leaf response to high irradiance (Poorter et al., 2009; Hogewoning et al., 2010b). Decreased R/B ratio might provoke high irradiance response of decreasing LA (Hernández and Kubota, 2014), which was associated with restriction of cell expansion or division induced by B (Appelgren, 1991; Folta et al., 2003; Dougher and Bugbee, 2004). Leaf extension in the vertical and horizontal directions is controlled by different genes. Blue light causes an imbalance in expression of these genes, resulting in inhibition of leaf expansion (Tsukaya, 1998). However, the effect of B dose on LA was species and cultivars specific. For example, Dougher and Bugbee (2001) tested the effect of B fraction on LA under high pressure sodium (HPS) and metal halide lamps $(\mathrm{MH})$, creating five $B$ fractions. They found LA of lettuce increased with increasing B fraction from 0 to $6 \%$ at $200 \mu \mathrm{mol} \cdot \mathrm{m}^{-2} \cdot \mathrm{s}^{-1}$ and from 0 to $2 \%$ at $500 \mu \mathrm{mol} \cdot \mathrm{m}^{-2} \cdot \mathrm{s}^{-1}$ under HPS treatments; yet there was little response to different $\mathrm{B}$ fraction under $\mathrm{MH}$ treatments $(6,12$, and $26 \%, \mathrm{~B}$ fraction). In this study, LA under $\mathrm{R}$ and $\mathrm{R} / \mathrm{B}=12$ treatments had no significant difference. The differences in these results suggested that other wavelengths except R and B in HPS or MH have promoting or inhibiting effects on leaf extension. In addition, increasing leaf number with increasing $\mathrm{R} / \mathrm{B}$ ratio up to 12 was due to shorter growth stage induced by increasing $\mathrm{R}$ (Ohashi-Kaneko et al., 2007).
Although $P_{\mathrm{n}}$ under $\mathrm{R}$ treatment was significantly lower than those under $\mathrm{R} / \mathrm{B}=12$ treatment, no significant difference was found in shoot dry weights under $\mathrm{R}$ and $\mathrm{R} / \mathrm{B}=12$ treatments, which were higher than other mixture of $\mathrm{R}$ and B treatments or B treatment. Similar results were also found in tomato, salvia, and petunia (Wollaeger and Runkle, 2014), and in lettuce, tomato, and komatsuna (Ohashi-Kaneko et al., 2007). For example, Wollaeger and Runkle (2014) reported that shoot dry weight of tomato, salvia, and petunia under $\mathrm{R}$ treatment increased by $48-112 \%$ compared to those under $\mathrm{R}$ supplemented with $25 \%$ or greater B treatments, along with increasing 47-130\% greater LA. Ohashi-Kaneko et al. (2007) also reported that shoot dry weight of lettuce, tomato, and komatsuna under $\mathrm{R}$ treatment were 14-29, 10-16, and 44$52 \%$ higher than those under mixture of $\mathrm{R}$ and $\mathrm{B}$ treatments and $\mathrm{B}$ treatment, respectively. In this study, this result was partly because $\mathrm{R}$ promoted petiole and stem elongation (Kim et al., 2004), resulting in loose leaf structure to capture much more light for growth. On the other hand, plants grown under $\mathrm{R}$ treatment had no reduction in LMA, LA and leaf number compared to plants grown $\mathrm{R} / \mathrm{B}=12$ treatment, not affecting light interception. Similarly, for the above parameters, there were no significant differences between $\mathrm{R} / \mathrm{B}=12$ and $\mathrm{R} / \mathrm{B}=8$ treatments. However, compared with $\mathrm{R} / \mathrm{B}=12$ treatment, a slight reduction in dry weight under $\mathrm{R} / \mathrm{B}=8$ treatment was due to higher $R_{\mathrm{d}}$ (Table 2). Based on above results, there might be a maximum threshold value of B for optimal lettuce growth under R-based light source.

\section{CONCLUSION}

In this study, our results showed that compared with monochromic $\mathrm{R}$ or $\mathrm{B}$, a combination of $\mathrm{R}$ and $\mathrm{B}$ was much more efficient in facilitating lettuce growth and photosynthesis. Lettuce plants under $\mathrm{R} / \mathrm{B}=1$ treatment exhibited the highest $P_{\mathrm{n}}$ and $A_{\max }$. An increase of $P_{\mathrm{n}}$ and $A_{\max }$ with decreasing $\mathrm{R} / \mathrm{B}$ ratio was mainly associated with stomatal characteristics. However, the highest shoot dry weight was observed under $\mathrm{R} / \mathrm{B}=12$ treatment with the greatest leaf number and LA. There was no positive relationship between $P_{\mathrm{n}}$ of single leaf and shoot dry weight accumulation. Therefore further studies should be constructed to investigate the relationship between $P_{\mathrm{n}}$ of entire plant and dry weight accumulation.

\section{AUTHOR CONTRIBUTIONS}

JW carried out the measurements, data analysis and drafted the manuscript. WL participated in part of measurements and data analysis. YT and QY made substantial guide about experiment design, and critically revised the manuscript.

\section{ACKNOWLEDGMENT}

This work was financially supported from the National High Technology Research and Development Plan of China (863 Project, grant No. 2013AA103007). 


\section{REFERENCES}

Aksenova, N. P., Konstantinova, T. N., Sergeeva, L. I., Macháčková, I., and Golyanovskaya, S. A. (1994). Morphogenesis of potato plants in vitro. I. Effect of light quality and hormones. J. Plant Growth Regul. 13, 143-146. doi: 10.1007/BF00196378

Appelgren, M. (1991). Effects of light quality on stem elongation of Pelargonium in vitro. Sci. Hortic. 45, 345-351. doi: 10.1016/0304-4238(91)90081-9

Bondada, B. R., and Syvertsen, J. P. (2003). Leaf chlorophyll, net gas exchange and chloroplast ultrastructure in citrus leaves of different nitrogen status. Tree Physiol. 23, 553-559. doi: 10.1093/treephys/23.8.553

Brown, C. S., Schuerger, A. C., and Sager, J. C. (1995). Growth and photomorphogenesis of pepper plants under red light-emitting diodes with supplemental blue or far-red lighting. J. Am. Soc. Hortic. Sci. 120, 808-813.

Christie, J. M. (2007). Phototropin blue-light receptors. Annu. Rev. Plant Biol. 58, 21-45. doi: 10.1146/annurev.arplant.58.032806.103951

Dougher, T. A., and Bugbee, B. (2001). Differences in the response of wheat, soybean and lettuce to reduced blue radiation. Photochem. Photobiol. 73, 199-207.

Dougher, T. A., and Bugbee, B. G. (2004). Long-term blue light effects on the histology of lettuce and soybean leaves and stems. J. Am. Soc. Hortic. Sci. 129, $467-472$.

Evans, J. R. (1988). Acclimation by the thylakoid membranes to growth irradiance and the partitioning of nitrogen between soluble and thylakoid proteins. Aust. J. Plant Physiol. 15, 93-106. doi: 10.1071/PP9880093

Farquhar, G. D., and Sharkey, T. D. (1982). Stomatal conductance and photosynthesis. Annu. Rev. Plant Physiol. 33, 317-345. doi: 10.1146/annurev.pp.33.060182.001533

Fischer, R. A., Rees, D., and Sayre, K. D. (1998). Wheat yield progress associated with higher stomatal conductance and photosynthetic rates, and cooler canopies. Crop Sci. 38, 1467-1475. doi: 10.2135/cropsci1998.0011183X003800060011x

Folta, K. M., Lieg, E. J., Durham, T., and Spalding, E. P. (2003). Primary inhibition of hypocotyl growth and phototropism depend differently on phototropinmediated increases in cytoplasmic calcium induced by blue light. Plant Physiol. 133, 1464-1470. doi: 10.1104/pp.103.024372

Franck, N., Vaast, P., Génard, M., and Dauzat, J. (2006). Soluble sugars mediate sink feedback down-regulation of leaf photosynthesis in field-grown Coffea arabica. Tree Physiol. 26, 517-525. doi: 10.1093/treephys/26.4.517

Genty, B., Briantais, J. M., and Baker, N. R. (1989). The relationship between the quantum yield of photosynthetic electron transport and quenching of chlorophyll fluorescence. Biochim. Biophys. Acta 990, 87-92. doi: 10.1016/S0304-4165(89)80016-9

Gifford, R. M., and Jenkins, C. L. (1981). "Prospects of applying knowledge of photosynthesis toward improving crop production," in Photosynthesis: CO2 Assimilation and Plant Productivity, Vol. 2, ed. Govindjee (New York, NY: Academic Press).

Goins, G. D., Yorio, N. C., Sanwo, M. M., and Brown, C. S. (1997). Photomorphogenesis, photosynthesis, and seed yield of wheat plants grown under red light-emitting diodes (LEDs) with and without supplemental blue lighting. J. Exp. Bot. 48, 1407-1413. doi: 10.1093/jxb/48.7.1407

Goins, G. D., Yorio, N. C., Sanwo-Lewandowski, M. M., and Brown, C. S. (1998). Life cycle experiments with Arabidopsis under red light-emitting diodes (LEDs). Life Support Biosph. Sci. 5, 143-149.

Hernández, R., and Kubota, C. (2014). Growth and morphological response of cucumber seedlings to supplemental red and blue photon flux ratios under varied solar daily light integrals. Sci. Hortic. 173, 92-99. doi: 10.1016/j.scienta.2014.04.035

Hernández, R., and Kubota, C. (2016). Physiological responses of cucumber seedlings under different blue and red photon flux ratios using LEDs. Environ. Exp. Bot. 121, 66-74. doi: 10.1016/j.envexpbot.2015.04.001

Hoenecke, M. E., Bula, R. J., and Tibbitts, T. W. (1992). Importance of 'blue' photon levels for lettuce seedlings grown under red-light-emitting diodes. HortScience 27, 427-430.

Hogewoning, S. W., Douwstra, P., Trouwborst, G., van Ieperen, W., and Harbinson, J. (2010a). An artificial solar spectrumsubstantially alters plant development compared with usual climate room irradiance spectra. J. Exp. Bot. 61, 1267-1276. doi: 10.1093/jxb/erq005
Hogewoning, S. W., Trouwborst, G., Maljaars, H., Poorter, H., van Ieperen, W., and Harbinson, J. (2010b). Blue light dose-responses of leaf photosynthesis, morphology, and chemical composition of Cucumis sativus grown under different combinations of red and blue light. J. Exp. Bot. 61, 3107-3117. doi: $10.1093 /$ jxb/erq132

Inoue, S. I., Kinoshita, T., Matsumoto, M., Nakayama, K. I., Doi, M., and Shimazaki, K. I. (2008). Blue light-induced autophosphorylation of phototropin is a primary step for signaling. Proc. Natl. Acad. Sci. U.S.A. 105, 5626-5631. doi: 10.1073/pnas.0709189105

Johkan, M., Shoji, K., Goto, F., Hashida, S. N., and Yoshihara, T. (2010). Blue light-emitting diode light irradiation of seedlings improves seedling quality and growth after transplanting in red leaf lettuce. HortScience 45, 1809-1814.

Kim, S. J., Hahn, E. J., Heo, J. W., and Paek, K. Y. (2004). Effects of LEDs on net photosynthetic rate, growth and leaf stomata of chrysanthemum plantlets in vitro. Sci. Hortic. 101, 143-151. doi: 10.1016/j.scienta.2003.10.003

Lee, S. H., Tewari, R. K., Hahn, E. J., and Paek, K. Y. (2007). Photon flux density and light quality induce changes in growth, stomatal development, photosynthesis and transpiration of Withania somnifera (L.) Dunal. plantlets. Plant Cell Tissue Organ Cult. 90, 141-151. doi: 10.1007/s11240-006-9191-2

Li, H., Tang, C., and Xu, Z. (2013). The effects of different light qualities on rapeseed (Brassica napus L.) plantlet growth and morphogenesis in vitro. Sci. Hortic. 150, 117-124. doi: 10.1016/j.scienta.2012.10.009

Li, H., Xu, Z., and Tang, C. (2010). Effect of light-emitting diodes on growth and morphogenesis of upland cotton (Gossypium hirsutum L.) plantlets in vitro. Plant Cell Tissue Organ Cult. 103, 155-163. doi: 10.1007/s11240-0109763-z

Li, T., Heuvelink, E., Dueck, T. A., Janse, J., Gort, G., and Marcelis, L. F. M. (2014). Enhancement of crop photosynthesis by diffuse light: quantifying the contributing factors. Ann. Bot. 114, 145-156. doi: 10.1093/aob/mcu071

Lichtenthaler, H. K., and Wellburn, A. R. (1983). Determination of total carotenoids and chlorophylls a and b of leaf extracts in different solvents. Biochem. Soc. Trans. 603, 591-592. doi: 10.1042/bst0110591

Lin, K. H., Huang, M. Y., Huang, W. D., Hsu, M. H., Yang, Z. W., and Yang, C. M. (2013). The effects of red, blue, and white light-emitting diodes on the growth, development, and edible quality of hydroponically grown lettuce (Lactuca sativa L. var. capitata). Sci. Hortic. 150, 86-91. doi: 10.1016/j.scienta.2012. 10.002

Matsuda, R., Ohashi-Kaneko, K., Fujiwara, K., Goto, E., and Kurata, K. (2004). Photosynthetic characteristics of rice leaves grown under red light with or without supplemental blue light. Plant Cell Physiol. 45, 1870-1874. doi: $10.1093 / \mathrm{pcp} / \mathrm{pch} 203$

Matsuda, R., Ohashi-Kaneko, K., Fujiwara, K., and Kurata, K. (2008). Effects of blue light deficiency on acclimation of light energy partitioning in PSII and CO2 assimilation capacity to high irradiance in spinach leaves. Plant Cell Physiol. 49, 664-670. doi: 10.1093/pcp/pcn041

McCree, K. J. (1972). The action spectrum, absorptance and quantum yield of photosynthesis in crop plants. Agric. Meteorol. 9, 191-216. doi: 10.1016/00021571(71)90022-7

Miao, Y. X., Wang, X. Z., Gao, L. H., Chen, Q. Y., and Qu, M. (2016). Blue light is more essential than red light for maintaining the activities of photosystem II and I and photosynthetic electron transport capacity in cucumber leaves. J. Integr. Agric. 15, 87-100. doi: 10.1016/S2095-3119(15)61202-3

Nanya, K., Ishigami, Y., Hikosaka, S., and Goto, E. (2012). Effects of blue and red light on stem elongation and flowering of tomato seedlings. Acta Hortic. 956, 261-266. doi: 10.17660/ActaHortic.2012.956.29

Nhut, D. T., Takamura, T., Watanabe, H., Okamoto, K., and Tanaka, M. (2003). Responses of strawberry plantlets cultured in vitro under superbright red and blue light-emitting diodes (LEDs). Plant Cell Tissue Organ Cult. 73, 43-52. doi: 10.1023/A:1022638508007

Ohashi-Kaneko, K., Matsuda, R., Goto, E., Fujiwara, K., and Kurata, K. (2006). Growth of rice plants under red light with or without supplemental blue light. Soil Sci. Plant Nutr. 52, 444-452. doi: 10.1111/j.1747-0765.2006.00063.x

Ohashi-Kaneko, K., Takase, M., Kon, N., Fujiwara, K., and Kurata, K. (2007). Effect of light quality on growth and vegetable quality in leaf lettuce, spinach and komatsuna. Environ. Control Biol. 45, 189-198. doi: 10.2525/ecb.45.189

Pfündel, E., and Baake, E. (1990). A quantitative description of fluorescence excitation spectra in intact bean leaves greened under intermittent light. Photosynth. Res. 26, 19-28. doi: 10.1007/BF00048973 
Poorter, H., Niinemets, U., Pooter, L., Wright, I. J., and Villar, R. (2009). Causes and consequences of vibration in leaf mass per area (LMA): a meta-analysis. New Phytol. 182, 565-588. doi: 10.1111/j.1469-8137.2009.02830.x

Shimazaki, K. I., Doi, M., Assmann, S. M., and Kinoshita, T. (2007). Light regulation of stomatal movement. Annu. Rev. Plant Biol. 58, 219-247. doi: 10.1146/annurev.arplant.57.032905.105434

Son, K. H., and Oh, M. M. (2013). Leaf shape, growth, and antioxidant phenolic compounds of two lettuce cultivars grown under various combinations of blue and red light-emitting diodes. HortScience 48, 988-995.

Sæbø, A., Krekling, T., and Appelgren, M. (1995). Light quality affects photosynthesis and leaf anatomy of birch plantlets in vitro. Plant Cell Tissue Organ Cult. 41, 177-185. doi: 10.1007/BF00051588

Takahashi, K., Fujino, K., Kikuta, Y., and Koda, Y. (1995). Involvement of the accumulation of sucrose and the synthesis of cell wall polysaccharides in the expansion of potato cells in response to jasmonic acid. Plant Sci. 111, 11-18. doi: 10.1016/0168-9452(95)04222-G

Tennessen, D. J., Singsaas, E. L., and Sharkey, T. D. (1994). Light-emitting diodes as a light source for photosynthesis research. Photosynth. Res. 39, 85-92. doi: $10.1007 / \mathrm{BF} 00027146$

Terfa, M. T., Solhaug, K. A., Gislerød, H. R., Olsen, J. E., and Torre, S. (2013). A high proportion of blue light increases the photosynthesis capacity and leaf formation rate of Rosa $\times$ hybrida but does not affect time to flower opening. Physiol. Plant. 148, 146-159. doi: 10.1111/j.1399-3054.2012.01698.x

Thornley, J. H. M. (1976). Mathematical Models in Plant Physiology: A Quantitative Approach to Problems in Plant and Crop Physiology. London: Academic Press.

Tripathy, B. C., and Brown, C. S. (1995). Root-shoot interaction in the greening of wheat seedlings grown under red light. Plant Physiol. 107, 407-411.

Tsukaya, H. (1998). Genetic evidence for polarities that regulate leaf morphogenesis. J. Plant Res. 111, 113-119. doi: 10.1007/BF02507157

Wang, H., Gu, M., Cui, J., Shi, K., Zhou, Y., and Yu, J. (2009). Effects of light quality on CO2 assimilation, chlorophyll-fluorescence quenching, expression of Calvin cycle genes and carbohydrate accumulation in Cucumis sativus. J. Photochem. Photobiol. B Biol. 96, 30-37. doi: 10.1016/j.jphotobiol.2009.03.010
Wang, X. Y., Xu, X. M., and Cui, J. (2015). The importance of blue light for leaf area expansion, development of photosynthetic apparatus, and chloroplast ultrastructure of Cucumis sativus grown under weak light. Photosynthetica 53, 213-222. doi: 10.1007/s11099-015-0083-8

Wojciechowska, R., Długosz-Grochowska, O., Kołton, A., and Żupnik, M. (2015). Effects of LED supplemental lighting on yield and some quality parameters of lamb's lettuce grown in two winter cycles. Sci. Hortic. 187, 80-86. doi: 10.1016/j.scienta.2015.03.006

Wollaeger, H. M., and Runkle, E. S. (2014). Growth of impatiens, petunia, salvia, and tomato seedlings under blue, green, and red light-emitting diodes. HortScience 49, 734-740.

Yorio, N. C., Goins, G. D., Kagie, H. R., Wheeler, R. M., and Sager, J. C. (2001). Improving spinach, radish, and lettuce growth under red lightemitting diodes (LEDs) with blue light supplementation. HortScience 36, $380-383$.

Yorio, N. C., Wheeler, R. M., Goins, G. D., Sanwo-Lewandowski, M. M., Mackowiak, C. L., Brown, C. S., et al. (1998). Blue light requirements for crop plants used in bioregenerative life support systems. Life Support Biosph. Sci. 5, 119-128.

Zeng, B., Wang, Q. Y., and Tang, C. M. (2008). Anatomic analysis on heterosis in three transgenic bt pest-resistant hybrid cotton (G. hirsutum L.). Acta Agron. Sin. 34, 496-505. doi: 10.3724/SP.J.1006.2008.00496

Conflict of Interest Statement: The authors declare that the research was conducted in the absence of any commercial or financial relationships that could be construed as a potential conflict of interest.

Copyright (c) 2016 Wang, Lu, Tong and Yang. This is an open-access article distributed under the terms of the Creative Commons Attribution License (CC BY). The use, distribution or reproduction in other forums is permitted, provided the original author(s) or licensor are credited and that the original publication in this journal is cited, in accordance with accepted academic practice. No use, distribution or reproduction is permitted which does not comply with these terms. 